\title{
ANALISIS PENERAPAN PRINSIP GOOD GOVERNANCE DI KANTOR SAMSAT AMURANG
}

\author{
Synta Tulle $^{1}$, Jullie J. Sondakh ${ }^{2}$, Lidia M. Mawikere ${ }^{3}$ \\ 1,2,3 Jurusan Akuntansi, Fakultas Ekonomi dan Bisnis, Universitas Sam Ratulangi, Jl. Kampus Bahu, Manado, \\ 95115, Indonesia \\ E-mail : syntatulle@gmail.com
}

\begin{abstract}
This research aims to know the implementation of good governance principles at Samsat Amurang office. Principles relating to the financial statements are the principle of fairness, accountability principles, principles of transparency, and the principle of responsibility. This study uses a qualitative method. This research was conducted by interviewing the head of UPTB Samsat Amurang office and treasurer of reception section. Based on the results of research implementation of the principle of good governance are the principle of fairness, accountability principles, transparency principles, and running well in accordance with the procedures and rules applicable, while the application of the principle of responsibility is about the comfort of society that still can not satisfy the community and not in accordance with the rules of the good application of responsibility principle.
\end{abstract}

Keywords: good governance

\section{PENDAHULUAN}

Good governance sangat penting untuk diterapkan di Indonesia. Karena sekarang ini banyak terjadi kejadian yang menyebabkan munculnya krisis kepercayaan, dimana banyak masyarakat yang mulai kehilangan kepercayaan terhadap pemerintah. Dalam menjalankan prinsip good governance diperlukan kerjasama dari semua pihak yaitu antara pemerintah dan masyarakat.

Tujuan utama dari penerapan prinsip good governance pada kantor Samsat Amurang yaitu kinerja organisasi semakin meningkat serta hak dan kewajiban masyarakat dapat terpenuhi. Dengan adanya keinginan untuk mewujudkan prinsip good governance, maka sistem penyelenggaraan pemerintah dan juga pelayanan yang ada pada kantor samsat harus diperhatikan prinsip-prinsip tentang pelayanan yang baik kepada masyarakat, responsibilitas, kewajaran, akuntabilitas serta transparansi. Penerapan prinsip good governance yang sesuai dan pelaksanaan pertanggungjawaban yang baik oleh Kantor Samsat akan membantu dalam pelaporan dan pertanggungjawaban kinerja serta pelayanan yang diberikan oleh Samsat Amurang dapat optimal. Kantor Samsat Amurang juga harus menerapkan standar akuntansi pemerintah dalam laporan keuangan Samsat yang baik dan mudah dimengerti oleh masyarakat agar masyarakat dapat mengetahui posisi keuangan dan kinerja keuangan dari pemerintah Samsat. Informasi-informasi dan laporan keuangan dari pemerintah Samsat dapat digunakan sebagai pertanggung jawaban dari pemerintah Samsat kepada masyarakat yang adalah selaku sumber dana. Itulah sebabnya Samsat Amurang dalam pelaporannya memerlukan standar yang berlaku untuk laporan keuangan dan pedoman untuk digunakan pemerintah kantor Samsat dalam membuat laporan keuangan yang baik dan sesuai dengan ketentuannya (Kesuma, 2017). 


\section{TINJAUAN PUSTAKA}

\subsection{Pengertian Akuntansi}

Akuntansi merupakan ilmu pencatatan transaksi, menggolongkan dan meringkas dengan cara yang mudah dipahami dan diukur dalam bentuk mata uang, atas transaksitransaksi atau kejadian-kejadian dalam keuangan perusahaan maupun instansi dan menginterpretasikan hasilnya (Tanor, 2015).

\subsection{Akuntansi Sektor Publik}

Akuntansi sektor publik merupakan suatu proses yang terdiri dari mencatat, mengklasifikasi, menganalisis dan membuat laporan kejadian-kejadian atau transaksitransaksi ekonomi yang nantinya menghasilkan berupa informasi keuangan untuk pihakpihak tertentu yang membutuhkan sebagai salah satu dasar pengambilan keputusan yang berlaku pada instansi Pemerintah tentang pengelolaan dana publik di lembaga-lembaga tinggi Negara dan Departemen-Departemen yang ada (Wiratna, 2015).

\subsubsection{Anggaran Sektor Publik}

Anggaran sektor publik merupakan rencana dari pendapatan, belanja dan tranfer dan ringkasan untuk pembiayaan-pembiayaan daerah seperti pelaksanaan program-program yang direncanakan disetiap daerah (Halim,2014).

\subsubsection{Pengendalian Anggaran}

Anggaran ini berfungsi untuk meyakinkan organisasi sektor publik bahwa organisasi mempunyai sumber dana untuk membiayai rencana program-program organisasi.

\subsection{Pengertian Standar Akuntansi Pemerintahan}

Standar Akuntansi Pemerintahan adalah suatu standar yang dipakai dalam melakukan pelaporan dan laporan keuangan dalam instansi pemerintah dengan menerapkan prinsipprinsip dalam penyusunannya.

\subsection{Pelaporan}

Pelaporan merupakan sesuatu kegiatan atau aktivitas yang adalah untuk menyampaikan jawaban dari hasil pekerjaan atau kegiatan pengawasan yang dilakukan.

\subsection{Pengertian Good Governance}

Pemerintahan yang baik adalah penyelenggaraan manajemen yang mengatur pembangunan dalam pertanggungjawaban kegiatan, berjalan sesuai dengan prinsip-prinsip demokrasi, efisien, kewajaran dalam pelaporan kegiatan, adanya keterlibatan masyarakat dalam pengambilan keputusan.

\subsubsection{Prinsip Good Governance}

Pemerintahan yang baik memiliki beberapa prinsip yang dikaitkan dengan laporan keuangan. Prinsip-prinsip good governance menurut Tim Pengembangan Tata Kelola Pemerintahan yang baik (BPKP) tersebut diuraikan sebagai berikut:

1. Prinsip kewajaran

2. Prinsip akutabilitas

3. Prinsip transparansi

4. Prinsip responsibilitas

\subsubsection{Penerapan Good Governance di Indonesia}

Penerapan prinsip good governance di Indonesia sendiri mulai diterapkan atau dilaksanakan sejak adanya era reformasi yang pada saat era reformasi tersebut telah adanya pergantian sistem pemerintahan yang mengharuskan adanya proses kegiatan demokrasi yang baik untuk dijalankan agar good governance menjadi suatu tembusan reformasi yang harus dipakai dan dilaksanakan dalam pemerintahan yang baru. 


\section{METODE PENELITIAN}

\subsection{Jenis Penelitian}

Penelitian ini menggunakan jenis penelitian deskritif dengan menggumpulkan datadata penelitian yang diperoleh dari kantor Samsat Amurang kabupaten Minahasa Selatan mengenai permasalahan penelitian.

\subsection{Tempat dan Waktu Penelitian}

Lokasi penelitian bertempat di Kantor Samsat Amurang. Jl. Trans Sulawesi, Pondang, Amurang Kabupaten Minahasa Selatan, Provinsi Sulawesi utara. Waktu pelaksanaan dimulai pada bulan Maret sampai Juni 2018.

\subsection{Prosedur Penelitiaan}

1. Kajian Awal

Mempelajari teori-teori yang berkaitan dengan prinsip good governance yaitu prinsip kewajaran, akuntabilitas, transparansi, dan responsibilitas.

2. Perancangan dan Persiapan Penelitian

3. Pengumpulan Data

Pengumpulan data penelitian yaitu dari hasil wawancara dan pengisian tabel responden oleh kepala UPTD Kantor Samsat Amurang, Kepala Tata Usaha, dan Bendahara penerimaan.

4. Pengelolaan Data

Pada tahap ini penulis mengelola data yang sudah ada dengan efektivitas.

5. Hasil dan Pembahasan.

\subsection{Jenis, Sumber dan Metode Pengumpulan data}

\subsubsection{Jenis data}

Penelitian ini menggunakan jenis data kualitatif sebagai dasar untuk mengetahui bagaimana pelaksanaan prinsip-prinsip good governance yang terapkan pada kantor Samsat Amurang.

\subsubsection{Sumber data}

Penelitian ini menggunakan sumber data primer dan data sekunder. Dalam penelitian, peneliti menggunakan data primer berupa hasil wawancara secara langsung tentang prinsip kewajaran, prinsip akuntabilitas, prinsip transparansi, dan prinsip responsibilitas dengan pimpinan Samsat Amurang dan bendahara penerimaan Sedangkan data sekunder berupa informasi-informasi tentang instansi pemerintahan dalam bentuk arsip maupun dengan mempelajari berbagai tulisan dalam buku, internet, jurnal, skripsi yang berhubungan dengan penelitian.

\subsubsection{Metode Pengumpulan data}

Dalam penelitian ini peneliti melakukan tanya-jawab secara langsung (wawancara) dengan pihak yang bersangkutan seperti Kepala UPTB Samsat dan bendahara penerimaan dalam instansi pemerintahan Samsat Amurang. Cara ini dilakukan untuk mendapatkan informasi mengenai pelaksanaan prinsip good governance di kantor Samsat Amurang, bagaimana prosedur pembayaran pada kantor Samsat Amurang. Pertanyaan penelitian diperlihatkan pada Tabel 3.1 


\section{Tabel 3.1 Pertanyaan penelitian}

\section{Kepala UPTB Samsat Amurang}

A. Prinsip Kewajaran:

1. Apakah di kantor Samsat Amurang sistem pembayaran pajaknya sesuai dengan aturannya?

B. Prinsip Transparansi

1. Bagaimana dengan perhitungan pembayaran pajak kendaraan bermotor?

\section{Bendahara Penerimaan}

C. Prinsip Akuntabilitas:

1. Apakah yang diterima oleh kantor Samsat atas pajak sudah sesuai dengan yang diberikan kepada masyarakat?

D. Prinsip Responsbilitas:

1. Bagaimana dengan yang diterima masyarakat tentang tanggungjawab dalam pelayanan yang diharapkan dalam proses pembayaran pajak?

\subsection{Metode Analisis}

Dalam pelaksanaan penelitian ini, metode analisis yang digunakan adalah deskriptif yaitu dengan membahas dan menanyakan permasalahan yang akan diangkat, dan dibandingkan dengan teori yang berkaitan atau keadaan serta menggambarkan dan menjelaskan sesuatu kejadian hingga dapat menarik kesimpulan dalam penelitian.

\section{HASIL PENELITIAN DAN PEMBAHASAN}

\subsection{Hasil Penelitian}

\subsubsection{Prinsip Kewajaran}

Penerapan prinsip good governance penting dilaksanakan dalam proses kegiatan pelayanan Samsat karena dapat membantu mempercepat dalam pelaksanaan pelayanan kepada masyarakat, contohnya dalam pengurusan dokumen-dokumen kendaraan bermotor. Penetapan pajak kendaraan bermotor oleh Samsat telah ditetapkan oleh Undang-Undang RI Nomor 28 Tahun 2009 tentang Pajak Daerah dan Retribusi Daerah. Pada kantor Samsat Amurang pembayaran pajak kendaraan tercantum disetiap STNK yaitu biaya pajak yang harus dikeluarkan untuk membayar pajak Kendaraan Bermotor sebesar 1,5 persen dari nilai jual kendaraan bermotor yang dimiliki. Misalnya harga jual kendaraan 6.000.000, itu berarti PKB yang harus dibayar yaitu 90.000 dengan catatan besar PKB akan menurun setiap tahun karena menyusutnya harga mobil/motor.

\subsubsection{Prinsip Akuntabilitas}

Pelaksanaan prinsip akuntabilitas di Kantor Samsat Amurang sementara diupayakan untuk dilaksanakan dengan baik karena adanya tugas dan tanggungjawab yang diberikan untuk pengelolaan kinerja kantor Samsat agar dapat terlaksana secara efektif, serta adanya sistem pemantauan kinerja penyeleggara pemerintah dan pengawasan dari kepala kantor Samsat atas kinerja karyawan. Tugas kantor Samsat dan penerapan prinsip good governance mempunyai kaitan dalam pelayanan kepada masyarakat, transparansi pembayaran, efektif dan efesien dalam menjalankan pelayanan karena itulah diperlukan pelaksanaan prinsip good governance agar dapat membantu proses pelayanan dan pelaporan oleh kantor Samsat Amurang.

\subsubsection{Prinsip Transparansi}

Kantor Samsat Amurang melaksanakan proses kegiatan pelayanannya dengan transparan agar dapat membantu proses pelayanan dan kepercayaan dari masyarakat. Bentuk transparansi yang dilakukan oleh kantor Samsat Amurang dalam pelayanannya kepada masyarakat adalah dalam bidang pelaporan. Samsat telah membuka situs resmi dalam pembayaran pajak kendaraan bermotor agar supaya masyarakat dapat secara langsung mengetahui kejelasan dan perincian pembayarannya secara langsung agar tidak terdapat 
kecurigaan terdapat administrasi yang dilakukan, Pembayarannya dapat melalui Bank/ATM dan nantinya akan mendapat tanda pelunasan dan sah dari kantor Samsat. Dengan adanya transparansi ini membantu pemerintah pusat dalam pengevaluasian dan pemantauan kinerja dan kerja dari Samsat Amurang dan membantu meningkatkan kepercayaan masyarakat kepada pemerintah terlebih Samsat Amurang.

\subsubsection{Responsibilitas}

Dalam pemberian pelayanan Samsat kepada masyarakat tentunya ada terdapat kelalaian dalam pelayanan misalnya kesalahan-kesalahan yang dilakukan oleh petugas penjaga, lamanya pelayanan, fasilitas kantor yang kurang memadai seperti kurangnya tempat duduk, panasnya ruangan pelayanan.

\subsection{Pembahasan Penerapan dan pelaksanaan Prinsip Good Governance di Kantor Samsat Amurang}

\subsubsection{Prinsip Kewajaran}

Berdasarkan penelitian yang dilakukan bahwa penerapan prinsip kewajaran good governance di Kantor Samsat Amurang akan diupayakan agar dapat berjalan dengan baik, serta pembayaran untuk pajak kendaraan bermotor tergantung pada Peraturan Pemerintah Daerah yang mengatur hal tersebut.

\subsubsection{Prinsip Akuntabilitas}

Berdasarkan penelitian yang dilakukan dalam meneliti penerapan prinsip akuntabilitas di kantor Samsat Amurang pertanggungjawabannya diupayakan sesuai dengan prosedur dan ketentuannya karena penerapannya berkaitan dengan pengenaan pajak kendaraan bermotor kepada wajib pajak dan laporannya yang merupakan bentuk pertanggungjawaban kantor Samsat Amurang dan menjadi alat pengawasan yang efektif yang dilakukan oleh pemerintah pusat untuk mengkoordiner dan sebagai bentuk pengawasan kinerja.

\subsubsection{Prinsip Transparansi}

Berdasarkan penelitian yang dilakukan, kantor Samsat Amurang telah menjalankan prinsip transparansi good governance untuk membantu dalam pemberian pelayanan kepada masyarakat yaitu membantu memudahkan pembayaran. Adapun mekanisme pembayaran yang dilakukan oleh kantor Samsat Amurang adalah transparan kepada masyarakat dan pelaporannya kepada pemerintah pusat dapat dikatakan baik karena terarah dan langsung dipantau oleh pemerintah pusat karena sistem yang ada di kantor Samsat itu adalah langsung dikirim ke pemerintah pusat, jika dalam melakukan pembayaran di Kantor Samsat Amurang data yang ada di Samsat Amurang akan langsung di proses dan dikirimkan ke Kantor Samsat Pusat. Hal tersebut membuat kemungkinan tidak adanya kecurangan dalam pembayaran dan pelaporan yang disajikan.

\subsubsection{Prinsip Responsibilitas}

Penerapan Prinsip responsibilitas di kantor Samsat Amurang dapat dilihat dari sejauh mana pelaksanaan kegiatan Samsat Amurang dalam menjalankan tugas dan tanggungjawabnya kepada masyarakat misalnya dengan adanya kepuasan pelayanan kepada masyarakat, oleh sebab itu kendala yang di dapat dalam responsiblitas ini yaitu pada pelayanan yang diberikan belum memuaskan bagi masyarakat karena belum lengkapkan fasilitas kantor Samsat Amurang yang sesuai dengan prinsip yang berlaku misalnya masih panasnya ruangan tempat pelayanan masyarakat, kurangnya tempat duduk dan lainnya.

\section{KESIMPULAN DAN SARAN}

\subsection{Kesimpulan}

Samsat terdiri dari 3 instansi yaitu Kepolisian, Dispenda, dan Jasa Raharja yang berwenang untuk mengatur dan mengurus urusan pemerintah, kepentingan masyarakat berdasarkan tugas dan tanggungjawab yang diembankan. Dengan adanya pembahasan sebelumya maka ditarik kesimpulan: 
1. Dalam pelaksanaan prinsip-prinsip good governance telah sesuai dengan Peraturan Pemerintah Nomor 8 Tahun 2006 tentang Pelaporan Keuangan dan Kinerja Instansi Pemerintah.

2. Prinsip-prinsip good governance di kantor Samsat Amurang telah diupayakan agar dapat berjalan dengan baik yaitu prinsip kewajaran dalam pelaporan, akuntabilitas pelayanan, transparansi pelaporan yang berkaitan dengan tanggungjawab dan pajak oleh kantor Samsat Amurang dan penerapan prinsip good governance yaitu prinsip responsibilitas yang berkaitan dengan pelayanan dan kenyamanan masyarakat sedang diupayakan oleh kantor Samsat untuk dilaksanakan semaksimal mungkin untuk kenyamanan masyarakat.

\subsection{Saran}

Berdasarkan hasil pembahasan dan kesimpulan data yang telah ada, maka saran atas penelitian antara lain:

1. Diharapkan Kantor Samsat Amurang selalu memberikan pelayanan yang baik dan mengusahakan efektif dan efesien dalam waktu pelayanan yang diberikan.

2. Kantor Samsat Amurang memberikan masukan kepada pemerintah pusat untuk renovasi gedung pelayanan agar memberikan kenyamanan bagi masyarakat yang datang.

\section{DAFTAR PUSTAKA}

Arikunto, S. 2013. Prosdur Penelitian: Suatu Pendekatan Praktik. Jakarta: Rineka Cipta.

Bachtiar, A dan M, Iskandar. 2013. Akuntansi Pemerintahan. Selemba Empat. Jakarta.

Bambang Jatmiko, 2013. Good Governance government and the effect on local government Performance. journal accounting.

Desi Handayani, 2013. Good Governance dan Kualitas Laporan Keuangan Pemerintah. Jurnal akuntansi dan keuangan Indonesia 2(12): 99-109.

Dissanayaka, DKK. 2015. "The Development Of Publikc Sector Accounting And Financial Reporting In Sri lanka".

Halim. 2013. Akuntansi Sektor Publik. Jakarta: Selemba Empat.

Hery, 2013. Cara Mudah Memahami Akuntansi (Inti Sari Konsep Dasar Akuntansi). Prenada Media Group. Jakarta.

Jefri, Jullie J Sondakh, dan Hendrik Gamaliel. 2017. Pengaruh Sistem Akuntansi Pemerintahan, Budaya Organisasi,Kinerja Aparatur Pemerintah Daerah, Peran APIP, Dan Sistem Pengendalian Intern Pemerintah Terhadap Penerapan Good Governance. Jurnal Riset Akuntansi dan Auditing "GOODWILL". Vol. 8, No 2.

Kemal Supriadi, 2013. Good Governance dan Kualitas Laporan Keuangan Pemerintah. Jurnal Akuntansi 5(2): 78-89.

Kesuma, P. 2017. Pengaruh Good Governance, Penerapan Standar Akuntansi Pemerintah, Sistem Pengendalian Internal Pemerintah dan Kompetensi Aparatur Pemerintah Terhadap Kualitas Laporan Keuangan Pemerintah Pada Satuan Kerja Kementerian Pariwisata. Magister Akuntansi Universitas Pancasila.

Kuncoro, Mudrajad. 2015. Metode Riset Untuk Bisnis dan Ekonomi. Edisi 3. Jakarta: Erlangga.

Mardiasmo. 2013. Perpajakan Edisi Revisi, Andi Offset. Jakarta.

Mohd Khirul. 2015. Good Governance and Organization Performance In Public Sector. International journal Administration 1(4): 63-68.

Priyanti, Novi. 2013. Pengantar Akuntansi. Penerbit PT. Indeks, Jakarta.

Pujiyanti, Fera. 2015. Akuntansi Dasar. Penerbit: Lembar Pustaka Indonesia. Tangerang.

Rajab, W. 2013. Buku Ajar Epidemiologi Untuk Mahasiswa Kebidanan pp. 165- 171.EGC: Jakarta.

Tendi, H. 2013. Penyusunan Anggaran Perusahaan. Graha Ilmu, Bandung. 